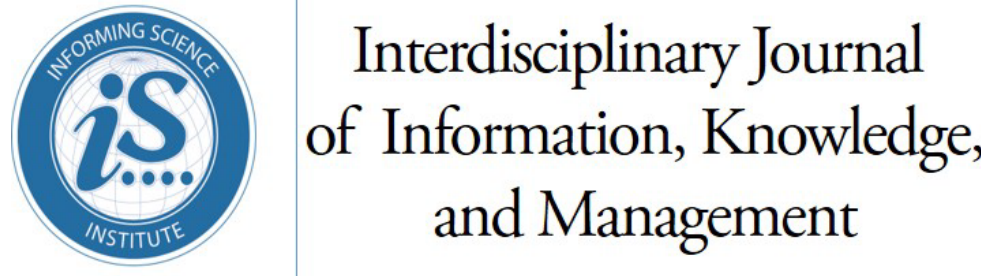

Volume 15, 2020
An Official Publication

of the Informing Science Institute

InformingScience.org

IJIKM.org

\title{
THE LONGITUdinAL EMPIRICAL STUDY OF ORGANIZATIONAL SOCIALIZATION AND KNOWLEDGE SHARING - FROM THE PERSPECTIVE OF JOB EMBEDDEDNESS
}

$\begin{array}{ll}\text { Chunjiang Yang* } & \begin{array}{l}\text { College of Business, Yantai Nanshan } \\ \text { University, Yantai, China } \\ \text { Aobo Chen }\end{array} \\ & \begin{array}{l}\text { School of Economics and Management, } \\ \text { Yanshan University, Qinhuangdao, } \\ \text { China }\end{array} \\ \text { * Corresponding author } & \end{array}$

\section{AbSTRACT}
Aim/Purpose Based on the social exchange theory, this study aimed to explore the un- derlying mechanisms and boundary conditions between organizational so- cialization and knowledge sharing.
Background
With the advent of the era of the knowledge economy, knowledge has been replacing traditional resources such as capital, labor, and land to be- come the critical resources of enterprises. The competitiveness of an or- ganization depends much on the effectiveness of its knowledge manage- ment; the success of its knowledge management largely relies upon em- ployees' motivation and willingness to engage in knowledge sharing.
Methodology This study is a longitudinal analysis of data collected from 281 newcomers in Chinese enterprises at two-time points with a one-month interval. Structural equation modeling (SEM) was conducted to test hypotheses by calculating standardized path coefficients and their significance levels.
Contribution
The study examined models linking organizational socialization and knowledge sharing that included organizational links and sacrifice as me- diators and trust as a moderator.

\footnotetext{
Accepting Editor Salah Kabanda | Received: October 19, 2019| Revised: December 20, 2019; January 20, 2020 | Accepted: January 21, 2020.

Cite as: Yang, C., \& Chen, A. (2020). The longitudinal empirical study of organizational socialization and knowledge sharing -From the perspective of job embeddedness. Interdisciplinary Journal of Information, Knowledge, and Management, 15, 1-23. https://doi.org/10.28945/4492
}

(CC BY-NC 4.0) This article is licensed to you under a Creative Commons Attribution-NonCommercial 4.0 International License. When you copy and redistribute this paper in full or in part, you need to provide proper attribution to it to ensure that others can later locate this work (and to ensure that others do not accuse you of plagiarism). You may (and we encourage you to) adapt, remix, transform, and build upon the material for any non-commercial purposes. This license does not permit you to use this material for commercial purposes. 
Findings Results show that the influences of organizational socialization on knowledge sharing change regularly over time. In the role management stage, coworker support and prospects for the future impact the practices of knowledge sharing through links and sacrifice. Moreover, the findings show that trust moderates the effect of links and sacrifice on employees' knowledge sharing.

Recommendations This study can help enterprises develop targeted human resource managefor Practitioners ment strategies, improve the degree of job embeddedness within the organization, and thus encourage more knowledge sharing among employees.

Recommendations First, researchers could pay attention to more underlying mechanisms and for Researchers boundary conditions in the relationship between organizational socialization and knowledge sharing. Second, focusing on specific cultural context and dimension of concepts may provide a new insight for the future study and help add greater theoretical precision to knowledge sharing.

Impact on Society First, this study suggests that coworker support and prospects for the future improve knowledge sharing within the organization. Second, understanding how job embeddedness (organizational links and organizational sacrifice) acts as a mediator enhancing knowledge sharing, managers should consider raising their attachment relationship to organizations from two aspects: links and sacrifice. Third, knowledge sharing takes place in a team-oriented context, where the success of the team requires highquality relationships among individual team members within the team as a whole.

Future Research Researchers in the future should employ experimental research design or utilize longitudinal data to ensure that the findings reveal causation. In addition, future research can investigate how the initial level and later changes of organizational socialization are associated with knowledge sharing beyond the observational scope of traditional cross-sectional and lagged research designs.

Keywords organizational socialization, job embeddedness, trust, knowledge sharing

\section{INTRODUCTION}

With the advent of the era of the knowledge economy, knowledge has become a critical resource in economies. The competitiveness of an organization depends much on the effectiveness of its knowledge management (North, Maier, \& Haas, 2018). Previous studies have contended that the benefit of the stock or amount of knowledge is limited unless such knowledge is shared and flows across individuals, teams, or organizations (Du Plessis, 2007). Knowledge sharing is defined as "the act of making knowledge available to others within the organization" (Ipe, 2003, p. 341). A multitude of studies have documented that knowledge sharing is crucial for achieving effectiveness and higher productivity at the individual level (Kim \& Lee, 2013), team level, and organizational level (Tsai, 2001). More and more organizations have invested in lots of knowledge management systems to facilitate knowledge sharing among their employees. However, researchers increasingly recognize the major problem that knowledge management processes depend on people rather than systems or technologies (Barley, Treem, \& Kuhn, 2018; Lee, Kim, \& Yun, 2018). For organizations to benefit from knowledge management, knowledge needs to be shared amongst employees to transform individual knowledge into organizational knowledge. The success of an organization's knowledge management largely relies upon its employees' motivation and willingness to engage in knowledge sharing (M. H. Wang \& Yang, 2016). How to increase the ability of managing knowledge sharing within and 
across the organization is one of the significant challenges facing contemporary organizations. Obviously, knowledge sharing means that individuals need to share their specialized knowledge, unique skills, expertise, and information, and the sharers needed to spend much time and energy to acquire these valuable resources in the past. In addition, knowledge sharing can benefit the organization, but it may undermine the competitive position and advantage of knowledge contributors and demand higher costs or risks from them. Thus, individuals may hide their valuable knowledge for their success, and thus knowledge sharing is particularly challenging for organizations (Chae, Park, \& Choi, 2019). Researchers need to investigate the factors that influence employees' willingness and motivation to engage in knowledge sharing (Bock, Zmud, Kim, \& Lee, 2005).

The literature on knowledge sharing has generally focused on the social and organizational contexts and incentive practices (Chae et al., 2019). However, there is little knowledge about the role of organizational socialization in knowledge sharing. Thus, the research presented herein verifies the relationship between the different organizational socialization strategies and knowledge sharing. Social exchange theory is an essential perspective for the study of interpersonal relationship or employee-organization relationship. According to the theory, various parties take actions and exchange valuable resources with each other according to the principle of reciprocity (Cropanzano, Anthony, Daniels, $\&$ Hall, 2017). Drawing on the social exchange theory, we propose that organizational socialization brings employees a variety of benefits, and employees would reward their organization through knowledge sharing as one of the critical discretionary behaviors.

The study also examines the underlying mechanism through which organizational socialization affects employees' knowledge-sharing. Employees under valid organizational socialization strategies such as coworker support and prospects for the future are likely to perceive more links within the organization and more sacrifice if they leave from an organization, resulting in job embeddedness (a secure attachment relationship with organization). In turn, the strong relationship between employees and their organization makes employees engage in more knowledge sharing behaviors for both organizational benefits and their own benefits. Thus, based on the social exchange theory, this study examines the mediating role of job embeddedness as a key mechanism linking organizational socialization to employees' knowledge sharing. In addition, trust (i.e., a psychological state comprising the intention to accept vulnerability based upon positive expectations of the intention or behavior of another) (Dirks \& Ferrin, 2002), as an important variable, acutely affects employees' attitudes and behaviors in the exchange relationship. Employees under organizational socialization strategies may be more likely to maintain their level of knowledge sharing, because they anticipate that they will receive the necessary support and benefits from their organization when the level of trust is high. Thus, trust may strengthen the positive effects of organizational socialization on knowledge sharing.

Overall, this study proposes that the influences of organizational socialization on knowledge sharing change regularly over time. In the role management stage, coworker support and prospects for future gains impact knowledge sharing through the links and sacrifice. In addition, trust moderates the effect of links and sacrifice on employees' knowledge sharing. This research provides several key contributions to enrich the understanding of knowledge sharing. First, by focusing on organizational socialization of newcomers, we answer the fundamental question: what are beneficial antecedents of knowledge sharing for employees? Second, this study conducts a sub-dimensional investigation of organizational socialization and job embeddedness, which provides new insights for the future study and add greater theoretical precision to the concept of "knowledge sharing". Third, exploring the boundary conditions of organizational socialization benefiting employees' knowledge sharing offers a more comprehensive understanding of the effects of organizational socialization on newcomers. 


\section{LITERATURE REVIEW}

\section{Organizational socialization}

To date, the research on knowledge sharing generally follows the social capital approach to investigate the potential antecedents of knowledge sharing (e.g., Akhavan \& Mahdi Hosseini, 2016; Cross \& Cummings, 2004; Inkpen \& Tsang, 2005). This line of research has contributed to our understanding of the important roles that contextual factors and organizational cues play in engendering effective knowledge sharing. Specifically, organizational socialization can build a variety of attachment relationships between employees and their organizations, forming critical situations. When entering a new organization, individuals need to learn the task requirements of their new jobs and the social behaviors acceptable in the organization in order to become functioning members of the organization. The process through which individuals acquire the knowledge and skills necessary to assume an organizational role is defined as organizational socialization (T. N. Bauer, Bodner, Erdogan, Truxillo, \& Tucker, 2007). Gericke, Albrecht, Pundt, and Deller (2019) suggested that organizational socialization has both proximal (role clarity, social acceptance, self-efficacy, fit) and distal outcomes of newcomers (commitment, job performance, turnover). For the organization, successful socialization of newcomers means better retention of employees, higher productivity, and reduced recruitment and training costs (T. N. Bauer et al., 2007; Yao \& Le, 2011). Successful socialization of newcomers means better role clarity, workgroup integration, task mastery, reduced role conflict, and greater willingness to share own knowledge. Prior studies of organizational socialization provided empirical evidence of the positive effects of this variable on knowledge sharing (Jeung, Yoon, \& Choi 2017; Mohan, 2017; Sarti, 2018). However, further research is needed regarding the specific mechanisms by which these effects occur and the boundary conditions under which organizational socialization improves knowledge sharing among employees.

\section{Job embeddedness}

Embeddedness is the extent of an individual's "stuckness", or enmeshing, within a social system (Mitchell, Holtom, Lee, Sablynski, \& Erez, 2001). Drawing on the sociological view, Mitchell, Holtom, Lee, Sablynski, and Erez (2001) metaphorically pointed out that job embeddedness is like a net or a web in which one can become "stuck" and it results from numerous external (or contextual) forces. These forces not only keep employees stay in the current organization, but also constitute a comprehensive framework for understanding their actions (Sekiguchi, Burton, \& Sablynski, 2008). Job embeddedness has three underlying dimensions: links (formal or informal connections to people, institutions, or locations), fit (compatibility or comfort with work or community environment), and sacrifice (perceived cost of material or psychological benefits forfeited by quitting) (Crossley, Bennett, Jex, \& Burnfield, 2007; Hom et al., 2009). Prior studies have shown that job embeddedness increases employees' organizational commitment and reduces employee turnover (Akgunduz \& Sanli, 2017; Hussain \& Deery, 2018; Zainuddin \& Noor, 2019). Moreover, Chen, Chou, and Wang (2010) found that job embeddedness also has a strong relationship with the effectiveness of knowledge work teams.

\section{Organizational socialization stages}

Integrating the definitions by domestic and foreign scholars, Chinese scholars Y. F. Wang and Zhu (2009) defined "organizational socialization" as "the process in which individuals adjust their work attitude, work behaviors, and values to adapt to the value system of a new organization, identify organizational goals and behavioral norms, and effectively integrate into the organization" (p. 1). Taking it as a multidimensional construct, Chao, O'Leary-Kelly, Wolf, Klein, and Gardner (1994) divided organizational socialization into six dimensions, which are performance proficiency, politics, language, people, organizational goals/values, and history. However, Taormina (1994) summarized organizational socialization into four dimensions: training, understanding, coworker support, and prospects for the future in the Chinese context. 
On the other hand, organizational socialization is divided into three stages by Feldman (1976), namely anticipatory socialization, accommodation, and role management. The first stage of the socialization process (anticipatory socialization) encompasses all the learning that occurs before the recruit enters the organization (Berkelaar \& Harrison, 2019; Clausen, 1968; Van Maanen, 1975). The main activities of newly hired individuals are: forming expectations about jobs such as transmitting, receiving, and evaluating information with prospective employers, and making decisions about employment (Dailey, 2016). Accommodation, the second stage of the socialization process, is a period in which the individual sees the true face of the organization and attempts to become a participating member of it. In this stage, newcomers mainly engage in learning new tasks, establishing new interpersonal relationships with coworkers, and clarifying their roles in the organization (Enneking \& Kleiner, 2017). Training and understanding are of vital importance to form newcomers' behaviors in the workplace in this stage. In the third stage of socialization (role management), newcomers face two main types of conflicts. The first type of conflicts is between work life and home life, such as schedules, demands by their families, and the effect of the job on the quality of home life. The second type of conflicts are between their work groups and other groups in the workplace. In this stage, coworker support and prospects for the future play an important role. In this study, we mainly focus on the role management stage of organizational socialization in order to gain insights on how employees solve conflicts and complete organizational socialization successfully.

\section{DEVELOPING HYPOTHESES}

\section{COWORKER SUPPORT AND ORGANIZATIONAL LINKS}

Coworker support refers to the extent to which employees have confidence in their coworker's willingness to assist them in carrying out work-related duties (Susskind, Kacmar, \& Borchgrevink, 2003), which includes providing encouragement and supporting one another while completing assigned tasks (Zhou \& George, 2001). Coworker support also involves emotional support such as concern for life (Pennaforte, 2016). Working with helpful and supportive colleagues encourages creation of interpersonal links within the organizational environment where members can communicate freely. Overall, coworkers are critical sources of task-related support (e.g., information and feedback) and social resources (e.g., care and encouragement) that promote goal accomplishments and well-being in the work context (Judge \& Zapata, 2015).

The Social Exchange Theory (SET) was established on the basis that both the employers and the employees may be devoted to each other in an emotional manner (Chernyak-Hai \& Rabenu, 2018). The theory essentially believes that people help each other even if they do not have to, and in return, help is expected from other people in the future. Social exchange relationships are associated with close personal attachments and open-ended obligations. People feel obliged towards those who helped them and respond accordingly. In this context, employees who have high anticipation of support from coworkers will have positive behaviors regarding their organizations. According to the social exchange theory, if employees perceive that the organization and coworkers meet their needs, then their positive emotions about their jobs and organizations increase (Golden \& Veiga, 2018). Support from the coworkers may generate robust social and normative contingencies for employees to reciprocate favors and sharing resources they received, thereby increasing their intention of organizational attachment. That is, if employees work in an environment where there are quality relationships between employees and coworkers, they feel obliged to respond via high levels of job embeddedness, especially organizational links. Specifically, employees who have trusting and quality relationships with their supervisors and coworkers are embedded in the social web of the organization. Such quality relationships with coworkers indicate that employees have good connections to individuals in the organization. The presence of adequate and quality coworker support also signals that the organization amply invests in employees in terms of learning and skill acquisition. Accordingly, employees who receive emotional support and instrumental aid from their coworkers when things get difficult 
in the workplace reciprocate via organizational links. Employees would engage in more mutual support and resource sharing to build and develop social networks within the organizations. Akgunduz and Sanli (2017) found that employees with more perceived organizational support are more likely to have a high level of job embeddedness. Karatepe (2013) found that frontline employees with work social support, including support from supervisors and coworkers, are more embedded in their jobs. Hence, the following hypothesis is proposed:

H1: Coworker support has a significant positive influence on organizational links.

\section{ORGANIZATIONAL LINKS AND KNOWLEDGE SHARING}

The greater extent of organizational links represents the employees' good relationship in their organizations. Several scholars have conceptualized social capital as a set of social resources embedded in relationships (Flap \& Boxman, 2017; Lin, 2017; Soulard, Knollenberg, Boley, Perdue, \& McGehee, 2018). Wide and close connections constitute social capital, which is defined as "the sum of the actual and potential resources embedded within, available through, and derived from the network of relationships possessed by an individual or social unit" (Nahapiet \& Ghoshal, 1998) that create valued outcomes (Burt, 2000). Social networks can facilitate access to information, resources, and opportunities, coordinate critical task interdependencies, overcome the dilemmas of cooperation and collective action, and promote a normative environment that facilitates communication and cooperation between actors. Positive organizational links provide increased opportunities for interpersonal contact. People have more positive feelings about sharing ideas and resources with those with whom they have developed a close relationship. Smith (2005) further observes that daily activities and human interactions of employees promote formal and informal knowledge sharing. In addition, the motivation and behaviors of sharing knowledge can be influenced by the perceived "cost of transfer" (Hansen, 1999). The higher the cost of a knowledge transfer, the less motivated the employee will be to share his or her knowledge with coworkers within the organization. Strong links reduce the cost of knowledge transfer (Szulanski, 1996). Specifically, when the knowledge to be transferred is tacit, strong ties between employees can facilitate the transfer. By establishing a higher level of intimacy between the provider and the recipient, strong organizational links increase the potential for extensive two-way knowledge sharing. Employees and coworkers who are bound by strong links typically have established rules of communication that enable them to exchange information and knowledge on a more complex and nuanced level. We therefore hypothesize:

H2: Organizational links have a significant positive influence on knowledge sharing.

H3: Organizational links mediate the relationship between coworker support and knowledge sharing.

Prospects for the future are the individual's perceptions of his or her prospects for a rewarding future within the new social context. When a worker realizes that his or her goals may not be forthcoming or attainable, it could lead to behaviors that are unproductive and counterproductive, or it could lead to resignation. Organizational sacrifice is the degree to which employees would have to give up or sacrifice things should they quit their job or leave the organization. Research evidence has shown that the more an employee gives up when leaving, the more difficult it is to sever employment with the organization. Conversely, when workers perceive they have little chance of success in an organization, it means they gain few visible and invisible benefits (Self \& Gordon, 2019). Besides, the perception that one has favorable prospects for success in an organization can result in more positive interests, such as active reward systems in a company. Based on the social exchange theory, after the employees have worked in the organization for an extended period, they get more interested in the organization and have a relatively clear understanding of future career development. If employees choose to leave the organization, they may suffer from a significant loss of benefits. When employees perceive that the loss caused by leaving the organization is increasing, the organization's binding 
force on employees is more significant, thus affecting the behavior of employees within the organization. Also, Yao and Le (2011) studied the "reality shock" caused by the gap between expectation and reality after employees entered the organization, which prevented employees from adapting to the organization and affected the results of organizational socialization, such as organizational attachment of employees. Thus, we postulate:

H4: Prospects for the future has a significant positive influence on organizational sacrifice.

The principle of exchange is among the most influential conceptual paradigms for understanding workplace behavior. When one party gives another party benefits, the individual expects the same return from the other party. The return of benefits is forced by reciprocity norms (Blau, 2017; Hann, 2018). Newcomers enter the organization over time, and the prospects for the future begin to have a significant impact on them. As noted earlier, organizational sacrifice is the sacrifice of material and/or psychological benefits that would be lost by quitting. The greater the sacrifices associated with leaving, the less likely individuals are to give up those benefits by quitting. A major role of organizational sacrifice is to encourage employees to become and remain participating members. At the stage of role management, employees gain more vested interests in the organization, and they begin to grow higher expectations for future development and career opportunities within the organization. That is, if employees choose to leave the organization at this stage, they will face more organizational sacrifices. To some extent, organizational sacrifice reflects various benefits from the organization. Due to all kinds of interests and future expectations, employees develop a close relationship with the organization (Allen, Eby, Chao, \& Bauer, 2017). In order to keep vested interests in the organization and future development of career, employees will not take the initiative to quit from the organization, and the organization will have a binding force on the employees and also create a positive force of knowledge sharing among the employees. Hence, this study puts forward the following hypotheses:

H5: Organizational sacrifice has a significant positive influence on knowledge sharing.

H6: Organizational sacrifice mediates the relationship between prospects for the future and knowledge sharing.

According to Fehr (2009), trust plays a role in almost all interpersonal relationships, and it penetrates friendship, family, and economic relationships. McEvily, Perrone, and Zaheer (2003) proposed that trust is the basic principle of an organization and a way to solve dependency and uncertainty within an organization or market. Bradach and Eccles (1989) found that trust strongly influences the mechanism of action within an organization. Previous studies have documented that as individuals grow closer in their relationship with one another, they are increasingly motivated to act in ways that benefit the other (Flavian, Guinalíu, \& Jordan, 2019). The intention to share valuable organizational knowledge with a coworker is likely to be heavily influenced by emotional relationships. Several studies have highlighted the importance of trust developed through close personal relationships (Rong, $\mathrm{Li}, \& \mathrm{Xie}, 2019)$. For instance, Le and Lei (2018) found that trust can improve the level of knowledge sharing within the organization.

Trust plays a vital role in knowledge sharing between peoples and explains the variance in transferring knowledge between employees in an organization. However, trust is not only an antecedent to knowledge sharing but also a boundary condition in the process of knowledge transfer. Specifically, trust in an organization affects how an employee assesses the future behavior of an organization in an exchange relationship with the organization. Trust provides positive clues or context regarding how facilitative or supportive the organization is expected to be in reaction to an employee's action, how forgiving in case of mistakes, and how appreciative the organization is predicted to be in response to contributions the employee makes (Ozyilmaz, Erdogan, \& Karaeminogullari, 2018). High trust in an organization involves expectation of benevolence and predictability in interactions, facilitating transformation of employee confidence into action. Thus, trust will strengthen the positive relationship between organizational links and knowledge sharing. Similarly, trust can enhance employees' confidence in access to resources and benefits and reduce the risk of loss. When trust is high, 
there is a greater level of predictability regarding how the organization will react, encouraging confident employees to turn their motivation into action, affecting their knowledge sharing. However, once the level of trust within the organization is low, employees can't trust their colleagues and leaders, they don't trust the operating mechanism within the organization, and they don't want to share their knowledge capital with other members in the organization. This becomes obstacles to knowledge sharing within the organization. Trust level plays a moderating role in the influence of organizational links and organizational sacrifice on knowledge sharing behaviors. Thus, we forward the following hypotheses:

H7: Trust moderates the relationship between organizational links and knowledge sharing.

H8: Trust moderates the relationship between organizational sacrifice and knowledge sharing.

All the hypotheses developed above form a theoretical model, which is represented in the diagram depicted in Figure 1.

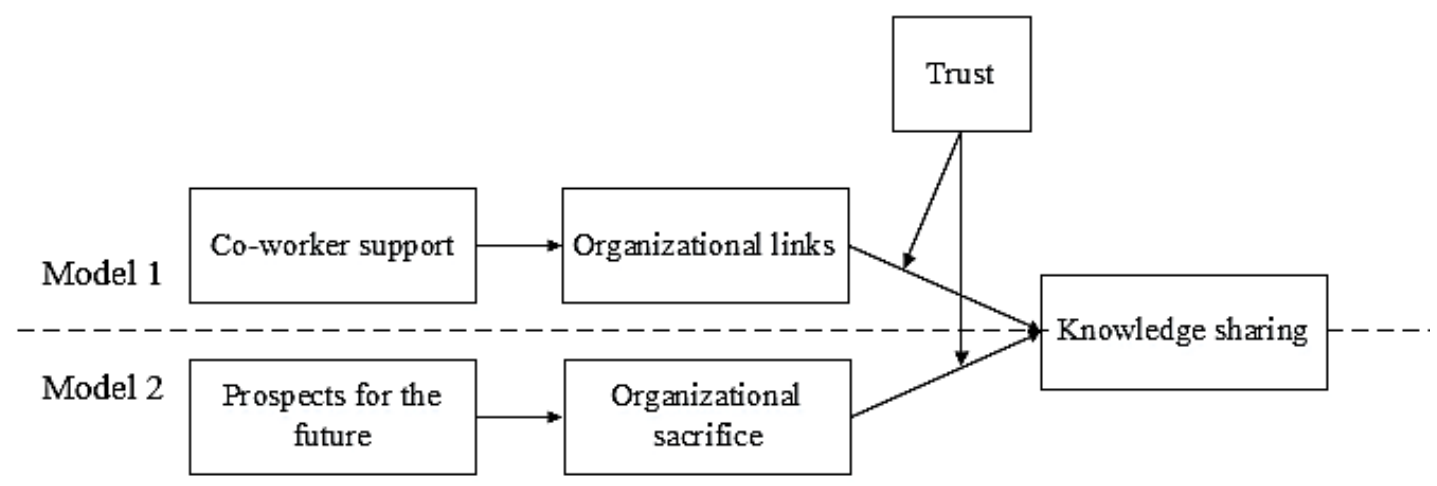

Figure 1: Proposed theoretical model

\section{METHOD}

To evaluate the proposed theoretical model empirically by testing hypotheses $\mathrm{H} 1$ through $\mathrm{H} 8$, a questionnaire survey was conducted of new employees in 10 Chinese companies. The collected survey data were analyzed using the Structural Equation Modeling technique. The subsections below document methodological specifics of research implementation.

\section{PARTICIPANTS AND PROCEDURES}

The research data were collected from 281 recently hired graduates in China. These graduates are often assumed to be neophytes with little or no experience of workplace realities. First, we recruited our participants through getting in touch with HR supervisors of 10 companies in China. We briefly introduced our research to the HR manager in order to get their agreement and help. Specifically, HR supervisors help us to ask whether their newcomers were willing to participate in the study and identify potential participants. All new employees must be already hired by the company in the current season but had not yet started their jobs. These new employees were from various functional units of the branch, including operation units, security units, finance units, marketing units, HR units, and customer service units. As an incentive, participants would receive $10 \mathrm{RMB}$ for each completed survey. Then we got the list of names and contact information of newcomers who can participant in the survey from human resources supervisors. We directly communicated with those employees via WeChat or telephone. After expressing gratitude for participating in the survey, we gave each em- 
ployee a unique code with a researcher-assigned identification number, to match employees' responses with their responses at different points of time. The research objectives, procedures, rules, and matters needing attention when completing the questionnaire were all explained to each participant in detail via WeChat or telephone.

The role management stage of organizational socialization focusing on the first 10 months of the newcomers' employment. Thus, before the newcomers started their jobs in the company, and they filled out a baseline survey that included measures of demographics. We sent them a link to the first survey (Time 1) via WeChat. After they started their employment in the company, we collected data from them at two-time points with a 1-month interval. At Time-2 (after ten months), employees received the links to the second survey via WeChat. Employees were asked to fill in the assigned code from researchers in each link. Participants completed measures of coworker support, prospects for the future, links, and sacrifice. At Time-3, employees received the link to the third survey via WeChat. The measure of knowledge sharing and trust were also completed.

During this survey process, 366 questionnaires were initially distributed at Time 1. Later, some participants dropped from the survey at Time 2 and Time 3 . After deleting some incomplete responses, we ended up with 281 valid responses from the third survey at Time 3 , yielding a response rate of $76.78 \%$. The range of their ages was mostly $(95.8 \%)$ from 23 to 26 years old. Gender distribution was nearly equal, with $54.8 \%$ of the participants self-identified as male, and $94.7 \%$ of them had a college degree. The summary of participant demographics is presented in Table 1.

Table 1: The demographics summary of survey participants

\begin{tabular}{|l|l|l|l|}
\hline Demographic Variable & Categories & Frequencies & Percentage \\
\hline \multirow{3}{*}{ Gender } & Male & 154 & 54.8 \\
\cline { 2 - 4 } & Female & 127 & 45.2 \\
\hline \multirow{4}{*}{ Age } & 22 or below & 6 & 2.1 \\
\cline { 2 - 4 } & $23-26$ & 269 & 95.8 \\
\cline { 2 - 4 } & 27 or above & 6 & 2.3 \\
\hline \multirow{4}{*}{ Education } & Junior college or below & 14 & 5.0 \\
\cline { 2 - 4 } & College degree & 266 & 94.7 \\
\cline { 2 - 4 } & Graduate degree & 1 & 0.4 \\
\hline
\end{tabular}

\section{MEASURING INSTRUMENTS}

The survey questionnaire, included as appendix, consists of multiple construct-measuring instruments adopted from previous research, all translated from English into Chinese with the translationback translation procedure (Brislin, 1980). All questionnaire items (questions) are of 7-point Likert scale, ranging from 1 ("Strongly Disagree") to 7 ("Strongly Agree"). Each of the adopted constructmeasuring instruments is explained below, construct by construct.

\section{ORGANIZATIONAL SOCIALIZATION}

Organizational socialization was measured using Taormina's scale (Taormina, 2004). Taormina's scale divides organizational socialization into four dimensions: training, understanding, coworker support, and prospects for the future. Only the items measuring the constructs "coworker support" and "prospects for the future", altogether 10 in total, were adopted. Cronbach's alpha of coworker support was 0.841. Cronbach's alpha of prospects for the future was 0.897 .

\section{JOB EMBEDDEDNESS \& ORGANIZATIONAL LINKS}

The construct "job embeddedness" was measured with 13 items adopted from C. J. Yang (2013). "Organizational links" was measured with three items, and "organizational sacrifice" was measured 
with five items. Cronbach's alpha of organizational links was 0.870 . Cronbach's alpha of organizational sacrifice was 0.810 .

\section{TRUST}

Trust was measured with seven items adopted from Cook and Wall (1980)'s scale. Cronbach's alpha of trust was 0.891 .

\section{KNOWLEDGE SHARING}

Knowledge sharing was measured with seven items adopted from Bock and Kim's (2002) scale. Cronbach's alpha of knowledge sharing was 0.888 .

\section{DATA ANALYSIS \& RESUltS}

The first author did data coding and data entry. During the process, the author did not find any issues. First, SPSS.21 software was used to conduct the descriptive statistical analysis, including means, standard deviations, and bivariate correlations of variables. It was also used to compute Cronbach's alphas to assess instrument validity and reliability. Second, AMOS17.0 software was used to conduct a series of confirmatory factor analyses to test whether the constructs had good convergent validity and discriminate validity. In addition, AMOS 17.0 software was used to conduct a structural equation modeling (SEM) to test the hypotheses.

Means, standard deviations, and bivariate correlations of variables in the study are presented in Table 2 and Table 3. The bivariate Pearson correlation coefficients (critical values) appear to be congruent with the proposed hypotheses. For example, Coworker support was positively correlated with organizational links $(r=0.539, \mathrm{p}<0.01)$ and knowledge sharing $(\mathrm{r}=0.485, \mathrm{p}<0.01)$. Organizational links was positively correlated with knowledge sharing $(\mathrm{r}=0.422, \mathrm{p}<0.01)$. Prospects for the future was positively correlated with organizational sacrifice $(\mathrm{r}=0.513, \mathrm{p}<0.01)$ and knowledge sharing $(\mathrm{r}=0.230$, $\mathrm{p}<0.01)$. Organizational links was positively correlated with knowledge sharing $(\mathrm{r}=0.280, \mathrm{p}<0.01)$. Results in Table 2 and Table 3 show that the value of AVE square root of constructs was greater than 0.5 .

The standard factor loadings of indicators on their respective latent variables were all significant (see Table 5). Thus, those results indicate that the convergent validity of constructs was acceptable. As shown in Table 4, confirmatory factor analyses were conducted, and the results showed that the constructs had good discriminate validity.

Table 2: Means Standard Deviations, and Bivariate Correlations among Studied Variables in the first Mode

\begin{tabular}{|l|l|l|l|l|l|l|l|}
\hline Variable & $\mathbf{M}$ & SD & $\begin{array}{l}\text { AVE square } \\
\text { root }\end{array}$ & & & & \\
\hline Coworker support & 5.327 & 0.860 & 0.723 & 0.5236 & - & - & - \\
\hline Organizational links & 5.550 & 0.770 & 0.776 & $.539^{* *}$ & 0.602 & - & - \\
\hline Trust & 5.459 & 1.186 & 0.719 & $.449^{* *}$ & $.555^{* *}$ & 0.516 & - \\
\hline Knowledge sharing & 5.210 & 0.815 & 0.717 & $.485^{* *}$ & $.422^{* *}$ & $.345^{* *}$ & 0.494 \\
\hline
\end{tabular}

Note: ${ }^{* * *} \mathrm{p}<0.001 ;{ }^{* *} \mathrm{p}<0.01 ;{ }^{*} \mathrm{p}<0.05$ (two-sided test). AVE square root for each construct are reported on the diagonal. 
Table 3: Means Standard Deviations, and Bivariate Correlations among Studied Variables in the second Model

\begin{tabular}{|l|l|l|l|l|l|l|l|}
\hline Variable & $\mathbf{M}$ & SD & $\begin{array}{l}\text { AVE square } \\
\text { root }\end{array}$ & & & & \\
\hline Prospects for the future & 4.811 & 1.113 & 0.782 & 0.620 & - & - & - \\
\hline Organizational sacrifice & 4.311 & 1.171 & 0.736 & $.513^{* *}$ & 0.541 & - & - \\
\hline Trust & 5.459 & 1.186 & 0.719 & $.339^{* *}$ & $.363^{* *}$ & 0.516 & - \\
\hline Knowledge sharing & 5.210 & 0.815 & 0.717 & $.230^{* *}$ & $.280^{* *}$ & $.345^{* *}$ & 0.494 \\
\hline
\end{tabular}

Note: ${ }^{* * *} \mathrm{p}<0.001 ;{ }^{* *} \mathrm{p}<0.01 ;{ }^{*} \mathrm{p}<0.05$ (two-sided test). AVE square root for each construct are reported on the diagonal.

Table 4: Confirmatory factor analyses of variables

\begin{tabular}{|l|l|l|l|l|l|}
\hline Variable & $\boldsymbol{\chi}^{\mathbf{2}} / \mathbf{d f}$ & RMR & GFI & AGFI & RMSEA \\
\hline Coworker support & 1.496 & 0.027 & 0.990 & 0.969 & 0.042 \\
\hline Organizational links & 1.487 & 0.023 & 0.992 & 0.965 & 0.044. \\
\hline Prospects for the future & 1.357 & 0.014 & 0.996 & 0.971 & 0.036 \\
\hline Organizational sacrifice & 2.159 & 0.020 & 0.997 & 0.954 & 0.064 \\
\hline Trust & 1.083 & 0.031 & 0.993 & 0.970 & 0.017 \\
\hline Knowledge sharing & 1.889 & 0.038 & 0.974 & 0.942 & 0.056 \\
\hline
\end{tabular}

Table 5: Factor Loadings of Indicators

\begin{tabular}{|c|c|c|}
\hline Construct & Indicators & Factor Loadings \\
\hline \multirow[t]{5}{*}{ Coworker support } & CS1 & $0.71 * *$ \\
\hline & $\mathrm{CS} 2$ & $0.67 * *$ \\
\hline & CS3 & $0.71 * *$ \\
\hline & CS4 & $0.72 * *$ \\
\hline & CS5 & $0.80 * *$ \\
\hline \multirow[t]{3}{*}{ Organizational links } & OL1 & $0.74 * *$ \\
\hline & OL2 & $0.89 * *$ \\
\hline & OL3 & $0.68^{* *}$ \\
\hline \multirow[t]{5}{*}{ Prospects for the future } & PF1 & $0.84 * *$ \\
\hline & PF2 & $0.56^{* *}$ \\
\hline & PF3 & $0.43 * *$ \\
\hline & PF4 & $0.33 * *$ \\
\hline & PF5 & $0.44 * *$ \\
\hline \multirow[t]{5}{*}{ Organizational sacrifice } & OS1 & $0.26^{* *}$ \\
\hline & OS2 & $0.81 * *$ \\
\hline & OS3 & $0.71 * *$ \\
\hline & OS4 & $0.45 * *$ \\
\hline & OS5 & $0.70^{* *}$ \\
\hline \multirow[t]{7}{*}{ Trust } & T1 & $0.66^{* *}$ \\
\hline & $\mathrm{T} 2$ & $0.65^{* *}$ \\
\hline & T3 & $0.76^{* *}$ \\
\hline & $\mathrm{T} 4$ & $0.68 * *$ \\
\hline & T5 & $0.69 * *$ \\
\hline & T6 & $0.89 * *$ \\
\hline & $\mathrm{T} 7$ & $0.66^{* *}$ \\
\hline
\end{tabular}




\begin{tabular}{|l|l|l|}
\hline Construct & Indicators & Factor Loadings \\
\hline Knowledge sharing & KS1 & $0.64^{* *}$ \\
\cline { 2 - 3 } & KS2 & $0.65^{* *}$ \\
\cline { 2 - 3 } & KS3 & $0.72^{* *}$ \\
\cline { 2 - 3 } & KS4 & $0.65^{* *}$ \\
\cline { 2 - 3 } & KS5 & $0.66^{* *}$ \\
\cline { 2 - 3 } & KS6 & $0.92^{* *}$ \\
\cline { 2 - 3 } & KS7 & $0.63^{* *}$ \\
\cline { 2 - 3 } & KS8 & $0.71^{* *}$ \\
\hline
\end{tabular}

Note: ${ }^{*} \mathrm{p}<0.05 .{ }^{* *} \mathrm{p}<0.01 . \mathrm{CS}=$ Coworker support; $\mathrm{PF}=$ Prospects for the future; $\mathrm{OS}=$ Organizational sacrifice; $\mathrm{T}=$ Trust; $\mathrm{KS}=$ Knowledge sharing.

\section{HYPOTHESIS TESTING}

We conducted a structural equation modeling (SEM) to test the hypotheses. Table 6 summarizes the results of hypothesis testing, and the standardized values of path coefficients are presented in form of the theoretical model in Figure 2 for ease of interpretation. All of the hypotheses about direct effects $(\mathrm{H} 1, \mathrm{H} 2, \mathrm{H} 4, \mathrm{H} 5)$ are supported by the empirical evidence. Mediating effects are tested by recomputing path coefficients while controlling for the mediating/moderating factor, and all of the hypotheses about meditating effects $(\mathrm{H} 3, \mathrm{H} 6, \mathrm{H} 7$ and $\mathrm{H} 8)$ are supported as well. Nevertheless, some special notes of explanation are in order.

In the case of $\mathrm{H} 3$, there is a significant and positive path from coworker support to knowledge sharing $(\beta=0.546, p<0.01)$. After controlling for the influence of organizational links, the path remains significant $(\beta=0.429, \mathrm{p}<0.01)$, but became weaker. The result provides support for hypothesis $\mathrm{H} 3$ such that organizational links mediate the relationship between coworker support and knowledge sharing. As to H6, similarly there is a significant and positive path from prospects for the future to knowledge sharing $(\beta=0.262, \mathrm{p}<0.01)$. However, after controlling for the influence of organizational sacrifice, the path became insignificant $(\beta=0.079, \mathrm{p}=0.359$, not significant) and also weaker. Therefore, the result provides support for the hypothesis that organizational sacrifice mediates the relationship between prospects for the future and knowledge sharing.

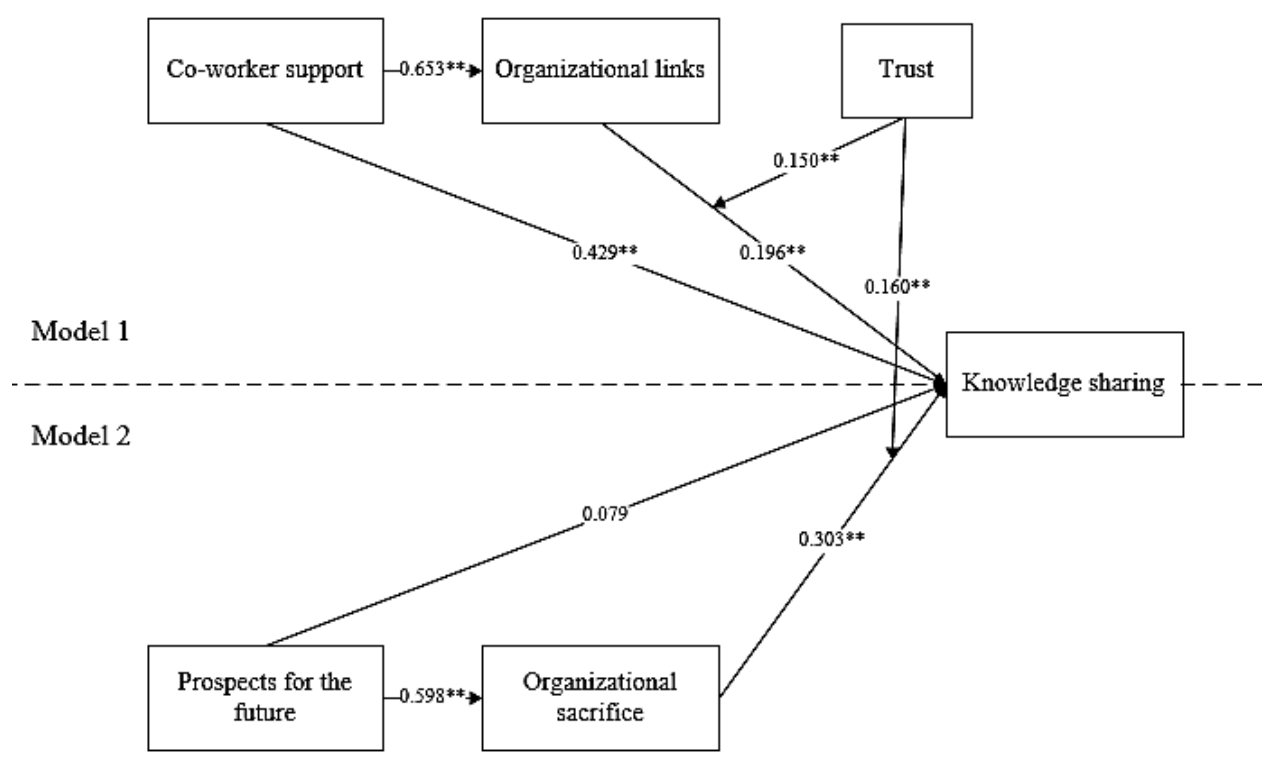

All direct and indirect effects are significant. ${ }^{*} \mathrm{p}<0.05,{ }^{* *} \mathrm{p}<0.01$.

Figure 2: Hypothesized model test results using structural equation modeling 
Finally, recall $\mathrm{H} 7$ that trust moderates the relationship between organizational links and knowledge sharing and $\mathrm{H} 8$ that trust moderates the relationship between organizational sacrifice and knowledge sharing. When testing these two hypotheses, we added the interaction of organizational links with trust in Model 1 and the interaction of organizational sacrifice with trust in Model 2. As shown in Figure 2, the results indicated that the joint effect of organizational links and trust on knowledge sharing was positive and significant $(\beta=0.15, \mathrm{p}<0.01)$. Thus, $\mathrm{H} 7$ was supported. Similarly, the joint effect of organizational sacrifice and trust on knowledge sharing was positive and significant $(\beta=0.160, \mathrm{p}<0.01)$. Thus, hypothesis H8 was supported. To examine the interactions, we plotted the simple slopes using the Johnson-Neyman technique (D. J. Bauer \& Curran, 2005). Figure 3 illustrates the effects of organizational links on knowledge sharing at the low and high levels of trust. The result shows that the direct effect of organizational links on knowledge sharing has a significant difference between high trust and low trust. Organizational links have a stronger influence on knowledge sharing when trust is high. Similarly, Figure 4 shows the effects of organizational sacrifice on knowledge sharing at the low and high levels of trust. The result shows that the direct effect of organizational sacrifice on knowledge sharing has a significant difference between high trust and low trust. Organizational sacrifice has a stronger influence on knowledge sharing when trust is high.

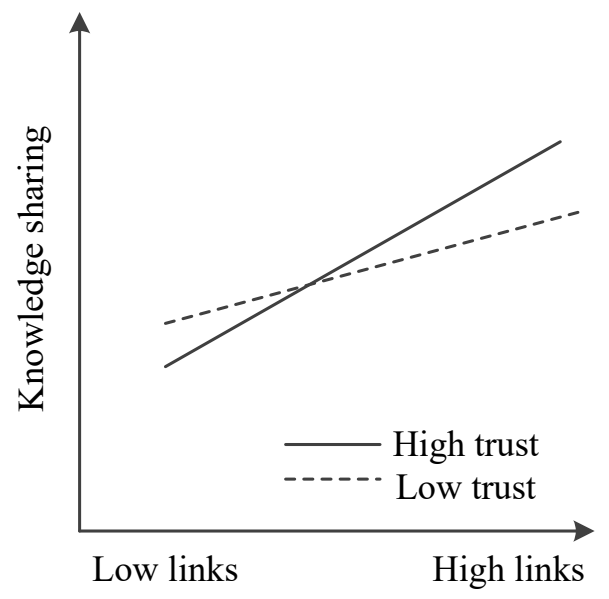

Figure 3: The interactive effect of organizational links and trust on knowledge sharing

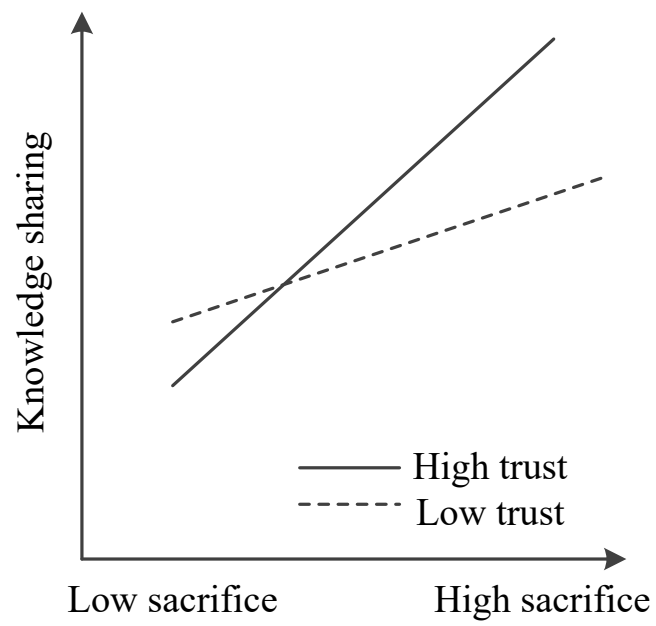

Figure 4: The interactive effect of organizational sacrifice and trust on knowledge sharing 
Table 6: The results of hypothesis testing

\begin{tabular}{|c|c|c|c|c|}
\hline Hypotheses & Hypotheses statement & $\beta$ & $\mathrm{p}$ & Results \\
\hline H1 & $\begin{array}{l}\text { Coworker support has a sig- } \\
\text { nificant positive influence on } \\
\text { organizational links }\end{array}$ & 0.653 & $<0.01$ & Support \\
\hline $\mathrm{H} 2$ & $\begin{array}{l}\text { Organizational links have a } \\
\text { significant positive influence } \\
\text { on knowledge sharing. }\end{array}$ & 0.196 & $<0.01$ & Support \\
\hline \multirow[t]{2}{*}{$\mathrm{H} 3$} & $\begin{array}{l}\text { Organizational links mediate } \\
\text { the relationship between } \\
\text { coworker support and } \\
\text { knowledge sharing }\end{array}$ & $\begin{array}{l}\text { coworker support- } \\
\text { knowledge sharing } \\
0.546\end{array}$ & $<0.01$ & Support \\
\hline & & $\begin{array}{l}\text { coworker support - } \\
\text { knowledge sharing } \\
\text { (after controlling for } \\
\text { the influence of organi- } \\
\text { zational links) } \\
0.429\end{array}$ & $<0.01$ & \\
\hline $\mathrm{H} 4$ & $\begin{array}{l}\text { Prospects for the future has } \\
\text { a significant positive influ- } \\
\text { ence on organizational sacri- } \\
\text { fice. }\end{array}$ & 0.598 & $<0.01$ & Support \\
\hline H5 & $\begin{array}{l}\text { Organizational sacrifice has } \\
\text { a significant positive influ- } \\
\text { ence on knowledge sharing. }\end{array}$ & 0.303 & $<0.01$ & Support \\
\hline \multirow[t]{2}{*}{ H6 } & $\begin{array}{l}\text { Organizational sacrifice me- } \\
\text { diates the relationship be- } \\
\text { tween prospects for the fu- } \\
\text { ture and knowledge sharing. }\end{array}$ & $\begin{array}{l}\text { prospects for the fu- } \\
\text { ture-knowledge sharing } \\
0.262\end{array}$ & $<0.01$ & Support \\
\hline & & $\begin{array}{l}\text { prospects for the fu- } \\
\text { ture-knowledge sharing } \\
\text { (after controlling for } \\
\text { the influence of organi- } \\
\text { zational sacrifice) } \\
0.079\end{array}$ & 0.359 & \\
\hline $\mathrm{H} 7$ & $\begin{array}{l}\text { Trust moderates the rela- } \\
\text { tionship between organiza- } \\
\text { tional links and knowledge } \\
\text { sharing. }\end{array}$ & 0.150 & $<0.01$ & Support \\
\hline $\mathrm{H} 8$ & $\begin{array}{l}\text { Trust moderates the rela- } \\
\text { tionship between organiza- } \\
\text { tional sacrifice and } \\
\text { knowledge sharing. }\end{array}$ & 0.160 & $<0.01$ & Support \\
\hline
\end{tabular}

\section{FINDING}

Drawing from the social exchange theory, we evaluated a theoretical model linking organizational socialization (coworker support and prospects for the future) to knowledge sharing, with job embeddedness (organizational links and organizational sacrifice) and trust included as a mediator and a 
moderator respectively. Our results show that coworker support and prospects for the future are associated with organizational links and sacrifice. In turn, the organizational links and sacrifice serve as a linking mechanism, providing an explanation of the process through which coworker support and prospects for the future result in more knowledge sharing. Furthermore, our results indicate positive interaction between organizational links and trust as well as between organizational sacrifice and trust in predicting knowledge sharing. These results offer a glimpse into the mechanisms by which organizational socialization (coworker support and prospects for the future) manifests itself in knowledge sharing and understanding of the boundary conditions surrounding its effectiveness.

\section{DISCUSSION}

Our research findings are consistent with that of some previous studies. First, colleague support can directly involve assisting coworkers with demands and supporting/showing concern for one another, which is likely to make employees increase their links with others, organizational fit, and sense of belonging (Chênevert, Kilroy, \& Bosak, 2019; Wolgast \& Fischer, 2017). For instance, Berkman (2000) found that social support could develop and extend more social networks of individuals. It is also argued that when individuals perceive that they are socially supported in the workplace, they are more likely to feel "central, included, valued, and respected" in their organization, which may lead to person-organization fit (Wiesenfeld, Raghuram, \& Garud, 2001, p. 218). In addition, job social support may create a more positive work environment (Carlson \& Perrewé, 1999) in which employees are more likely to feel valued and increase organizational identification. Second, newcomers who had a more extensive social network with their colleagues would perceive greater social pressure for sharing their knowledge, because a good relationship results in high expectation of colleagues, including favorable actions. Chow and Chan (2008) found that links with others contributed to a person's volition to share knowledge based on the data from 190 managers of Hong Kong firms. Third, in today's fast changing world, people turn to personal relationships for guidance or help, and the quality of these relationships is mainly determined by the level of trust. Many studies have suggested that trust or mutual trust among members is one of many factors critical to the success of knowledge sharing (Chow \& Chan, 2008). In addition, a variety of studies (such as Bal, de Lange, Ybema, Jansen, \& van der Velde, 2011; Chang \& Wong, 2010) investigated the moderating role of "trust" and recognized trust as an important factor for the goodness of an organization. Trust is essential for maintaining cooperation within the organizational settings (Williams \& Belkin, 2016). To some extent, our results support these arguments in the previous studies.

However, some researchers point out that there is a difference in job embeddedness and trust between the East Asian and Western cultures (I. Yang \& Horak, 2019). One is based on the sharedness of category membership (Western) while the other is based on indirect interpersonal connections (East Asian), and this difference may in fact stem from two distinct psychological processes (Akgunduz \& Cin, 2015). Meanwhile, the cognition and behavior of links and fit may differ across certain cultural contexts. Additionally, the findings point to a positive aspect of trust that trust strengthens the positive relationships between organizational links and organizational sacrifice and knowledge sharing. However, this result is inconsistent with some previous studies. Molina-Morales, Martínez-Fernández, and Torlò (2011) found that trust increased the opportunity of misallocating precious resources and/or unnecessary risks in the western context. Skinner, Dietz, and Weibel (2014) found that trust could become a poisoned chalice for one or other of the parties involved. Both of these studies suggested that trust might have a dark side.

\section{CONCLUSION}

\section{THEORETICAL IMPLICATIONS}

The findings of this study have several important theoretical implications. First, previous studies on organizational socialization are mainly focused on its positive influence on newcomers' performance, 
while this study turned attention to another vital problem for knowledge industry-employees' knowledge sharing. By examining the effect of organizational socialization on knowledge sharing and its underlying mechanisms and boundary condition, this study extended the understanding of the roles of organizational socialization of newcomers.

Second, this study did a sub-dimensional investigation of organizational socialization and job embeddedness, which provides new insight for future research. Prior studies in the areas of organizational socialization and job embeddedness did not consider the specificity of their subdimensions, but instead regarded organizational socialization and job embeddedness as a whole construct when exploring their effects respectively (Batistič, 2018; Nguyen, Taylor, \& Bergiel, 2017; Nifadkar, 2018). Thus, most studies failed to take into account the different mechanisms for different dimensions of organizational socialization and job embeddedness. In response to the call for sub-dimensional research, our study focused on the sub-dimension of organizational socialization (coworker support and prospects for the future) and job embeddedness (organizational links and organizational sacrifice) and investigated their effects on knowledge sharing and different mechanisms in such relationships respectively.

Third, this research explored the boundary conditions that qualify the relationship between organizational links and sacrifice. Although previous research has underlined the importance of trust (e.g., Olaisen \& Revang, 2017; Yasir \& Majid, 2017), to the best of our knowledge, researchers have not yet explored the moderating role of trust in the relationship of organizational links and sacrifice with knowledge sharing. Our results show that trust is important, as the positive effects of organizational links and sacrifice are strengthened when trust is high. Therefore, the relationships between organizational links and sacrifice and knowledge sharing within the organization should not be regarded as constant, since they depend on the organizational context, such as trust. In other words, these relationships are not the same for all organizations, but differ depending on organizational trust. As such, this study reinforces the idea that trust should be considered as a means to account for heterogeneity in the relationships between organizational links and sacrifice and knowledge sharing. It contributes to the literature on job embeddedness and knowledge sharing and is one more step forward toward a better understanding of how trust influence employees' perceptions and responses to complex organizational socialization (Yasir \& Majid, 2017).

\section{MANAGERIAL IMPLICATIONS}

Some practical suggestions for management may be made based on the findings of this study. First, coworker support and prospects for the future may improve knowledge sharing within the organization. It would be beneficial for organizations to develop an environment or "culture" of support, including fostering support among coworkers. In addition, organizations should nurture a positive perspective and promising vision among newcomers.

Second, job embeddedness (organizational links and organizational sacrifice) enhances knowledge sharing as a mediator. Managers should consider strengthening employees' attachment relationship to the organization from two aspects: organizational links and organizational sacrifice. Specifically, links can be increased through team cooperation or complicated task, more communication with customers to achieve work value, and regularly organizing reunions and holiday events. Organizational captures the perceived cost of material or psychological benefits that may be forfeited by leaving one's job. Organizational sacrifice can be increased by increasing job or organizational rewards, offering paid leave and flexible work schedules, and meeting employees' needs for emotional and mental health.

Third, trust plays an important role in improving knowledge sharing within the organizations. Managers should encourage employees to grow trust in their teams and organizations. Specifically, managers should exhibit empathy and sensitivity to the needs of staff members. In addition, managers 
can also try to gain more trust from their employees. For example, managers should behave approachable and friendly, show support for team members even when they make mistakes, balance the need for results with being considerate of others and their feelings, work hard to win over people by being respectful of their ideas and perspectives, and ensure that words and actions match.

\section{LIMITATIONS AND FUTURE DIRECTIONS}

This study has some limitations nevertheless. First, it did not use the ideal approach of random sampling, but adopted the convenience sampling method instead for collecting survey data. However, the vast majority of previous studies relied on the convenience samples method (Sarstedt, Bengart, Shaltoni, \& Lehmann, 2018), and the findings of this study may still be generalizable to some extent. Future research can use additional samples (possibly with alternative sampling methods) to investigate the validity and transportability of our findings. Second, the study used the time-lagged design to collect survey data at different points of time, which limits our ability to make inference of causal relations. Thus, future research should employ the experimental or longitudinal design to ensure that the conclusion reflect causation. In addition, future research can investigate how the initial level and changing trends of organizational socialization are associated with knowledge sharing -- beyond the limited observational scope of the traditional cross-sectional and lagged design. Third, there may be other mechanisms underlying the relationship between organizational socialization and knowledge sharing. Hence, researchers can enrich and improve our theoretical model by conducting studies based on other theoretical assumptions.

\section{REFERENCES}

Akgunduz, Y., \& Cin, F. M. (2015). Job embeddedness as a moderator of the effect of manager trust and distributive justice on turnover intentions. Anatolia, 26(4), 549-562. https://doi.org/10.1080/13032917.2015.1020504

Akgunduz, Y., \& Sanli, S. C. (2017). The effect of employee advocacy and perceived organizational support on job embeddedness and turnover intention in hotels. Journal of Hospitality and Tourism Management, 31(13), 118-125. https://doi.org/10.1016/i.jhtm.2016.12.002

Akhavan, P., \& Mahdi Hosseini, S. (2016). Social capital, knowledge sharing, and innovation capability: An empirical study of R\&D teams in Iran. Technology Analysis \& Strategic Management, 28(1), 96-113. https://doi.org/10.1080/09537325.2015.1072622

Allen, T. D., Eby, L. T., Chao, G. T., \& Bauer, T. N. (2017). Taking stock of two relational aspects of organizational life: Tracing the history and shaping the future of socialization and mentoring research. Journal of Applied Psychology, 102(3), 324-337. https://doi.org/10.1037/apl0000086

Bal, P. M., de Lange, A. H., Ybema, J. F., Jansen P. G. W., \& van der Velde, M. E. G. (2011). Age and trust as moderators in the relation between procedural justice and turnover: A large-scale longitudinal study. $A p$ plied Psychology, 60(1), 66-86. https://doi.org/10.1111/j.1464-0597.2010.00427.x

Barley, W. C., Treem, J. W., \& Kuhn, T. (2018). Valuing multiple trajectories of knowledge: A critical review and agenda for knowledge management research. Academy of Management Annals, 12(1), 278-317. https://doi.org/10.5465/annals.2016.0041

Batistič, S. (2018). Looking beyond - socialization tactics: The role of human resource systems in the socialization process. Human Resource Management Review, 28(2), 220-233. https://doi.org/10.1016/j.hrmr.2017.06.004

Bauer, D. J., \& Curran, P. J. (2005). Probing interactions in fixed and multilevel regression: Inferential and graphical techniques. Multivariate Behavioral Research, 40(3), 373-400. https://doi.org/10.1207/s15327906mbr4003-5

Bauer, T. N., Bodner, T., Erdogan, B., Truxillo, D. M., \& Tucker, J. S. (2007). Newcomer adjustment during organizational socialization: A meta-analytic review of antecedents, outcomes, and methods. Journal of Applied Psychology, 92(3), 707-721. https://doi.org/10.1037/0021-9010.92.3.707 
Organizational socialization and knowledge sharing

Berkelaar, B. L., \& Harrison, M. A. (2019). Organizational socialization. Cambridge, MA: Oxford University Press. https://doi.org/10.1093/acrefore/9780190228613.013.127

Berkman, L. F. (2000). Social support, social networks, social cohesion and health. Social Work in Health Care, 31(2), 3-14. https://doi.org/10.1300/J010v31n02-02

Blau, P. (2017). Exchange and power in social life. New York, NY: Wiley. https://doi.org/10.4324/9780203792643

Bock, G. W., \& Kim, Y. G., (2002). Breaking the myths of rewards: An exploratory study of attitudes about knowledge sharing. Information Resources Management Journal, 15(2), 14-21. https://doi.org/10.4018/irmj.2002040102

Bock, G. W., Zmud, R. W., Kim, Y. G., \& Lee, J. N. (2005). Behavioral intention formation in knowledge sharing: Examining the roles of extrinsic motivators, social-psychological factors, and organizational climate. MIS Quarterly, 29(1), 87-111. https://doi.org/10.2307/25148669

Bradach, J. L., \& Eccles, R. G. (1989). Price, authority, and trust: From ideal types to plural forms. Annual Review of Sociology, 15(1), 97-118. https://doi.org/10.1146/annurev.so.15.080189.000525

Brislin, R. W. (1980). Translation and content analysis of oral and written materials. In H. C. Triandis \& J. W. Berry (Eds.), Handbook of cross cultural psychology (pp. 389-444). Boston, MA: Methodology, Allyn and Bacon.

Burt, R. S. (2000). The network structure of social capital. Research in Organizational Behavior, 22, 345-423. https://doi.org/10.1016/S0191-3085(00)22009-1

Carlson, D. S., \& Perrewé, P. L. (1999). The role of social support in the stressor-strain relationship: An examination of work-family conflict. Journal of Management, 25(4), 513-540. https://doi.org/10.1177/014920639902500403

Chae, H., Park, J., \& Choi, J. N. (2019). Two facets of conscientiousness and the knowledge sharing dilemmas in the workplace: Contrasting moderating functions of supervisor support and coworker support. Journal of Organizational Behavior, 40(4), 387-399. https://doi.org/10.1002/job.2337

Chang, H. H., \& Wong, K. H. (2010). Adoption of e-procurement and participation of e-marketplace on firm performance: Trust as a moderator. Information \& Management, 47(5), 262-270. https://doi.org/10.1016/j.im.2010.05.002

Chao, G. T., O’Leary-Kelly, A. M., Wolf, S., Klein, H. J., \& Gardner, P. D. (1994). Organizational socialization: Its content and consequences. Journal of Applied Psychology, 79(5), 730-743. https://doi.org/10.1037/00219010.79.5.730

Chen, J. R., Chou, T. C., \& Wang, T. W. (2010). The organizational context, job embeddedness, and effectiveness of managing knowledge work teams. Journal of Applied Business Research, 26(5), 19-27. https://doi.org/10.19030/jabr.v26i5.315

Chênevert, D., Kilroy, S., \& Bosak, J. (2019). The role of change readiness and colleague support in the role stressors and withdrawal behaviors relationship among health care employees. Journal of Organizational Change Management, 32(2), 208-223. https://doi.org/10.1108/JOCM-06-2018-0148

Chernyak-Hai, L., \& Rabenu, E. (2018). The new era workplace relationships: Is social exchange theory still relevant? Industrial and Organizational Psychology, 11(3), 456-481. https://doi.org/10.1017/iop.2018.5

Chow, W. S., \& Chan, L. S. (2008). Social network, social trust and shared goals in organizational knowledge sharing. Information \& Management, 45(7), 458-465. https://doi.org/10.1016/j.im.2008.06.007

Clausen, J. A. (1968). Recent developments in socialization theory and research. The ANNALS of the American Academy of Political and Social Science, 377(1), 139-155. https://doi.org/10.1177/000271626837700115

Cook, J., \& Wall, T. (1980). New work attitude measures of trust, organizational commitment and personal need non-fulfilment. Journal of Occupational Psychology, 53(1), 39-52. https://doi.org/10.1111/j.2044$\underline{\text { 8325.1980.tb00005.x }}$

Cropanzano, R., Anthony, E. L., Daniels, S. R., \& Hall, A. V. (2017). Social exchange theory: A critical review with theoretical remedies. Academy of Management Annals, 11(1), 479-516. https://doi.org/10.5465/annals.2015.0099 
Cross, R., \& Cummings, J. N. (2004). Tie and network correlates of individual performance in knowledge-intensive work. Academy of Management Journal, 47(6), 928-937. https://doi.org/10.5465/20159632

Crossley, C. D., Bennett, R. J., Jex, S. M., \& Burnfield, J. L. (2007). Development of a global measure of job embeddedness and integration into a traditional model of voluntary turnover. Journal of Applied Psychology, 92(4), 1031-1042. https://doi.org/10.1037/0021-9010.92.4.1031

Dailey, S. L. (2016). I'm new... again: Reconceptualizing the socialization process through rotational programs. Communication Studies, 67(2), 183-208. https://doi.org/10.1080/10510974.2016.1145130

Dirks, K. T., \& Ferrin, D. L. (2002). Trust in leadership: Meta-analytic findings and implications for research and practice. Journal of Applied Psychology, 87(4), 611-628. https://doi.org/10.1037//0021-9010.87.4.611

Du Plessis, M. (2007). The role of knowledge management in innovation. Journal of Knowledge Management, 11(4), 20-29. https://doi.org/10.1142/S0219649209002427

Enneking, J., \& Kleiner, B. (2017). Excellence in organizational socialization. Global Education Journal, 2017(1), 50-58.

Fehr, E. (2009). On the economics and biology of trust. Journal of the European Economic Association, 7(2-3), 235266. https://doi.org/10.1162/JEEA.2009.7.2-3.235

Feldman, D. C. (1976). A contingency theory of socialization. Administrative Science Quarterly, 21(3), 433-452. https://doi.org/10.2307/2391853

Flap, H., \& Boxman, E. (2017). Getting started: The influence of social capital on the start of the occupational career. In R. Dubos (Ed.), Social capital theory and research (pp. 159-181). New York, NY: Aldine de Gruyter. https://doi.org/10.4324/9781315129457-7

Flavian, C., Guinalíu, M., \& Jordan, P. (2019). Antecedents and consequences of trust on a virtual team leader. European Journal of Management and Business Economics, 28(1), 2-24. https://doi.org/10.1108/EJMBE-11$\underline{2017-0043}$

Gericke, D., Albrecht, A. G., Pundt, L., \& Deller, J. (2019). Organizational socialization: How can organizations support refugee newcomers' adjustment? Academy of Management Proceedings, 2019(1), 13901. Briarcliff Manor, NY: Academy of Management. https://doi.org/10.5465/AMBPP.2019.13901abstract

Golden, T. D., \& Veiga, J. F. (2018). Self-estrangement's toll on job performance: The pivotal role of social exchange relationships with coworkers. Journal of Management, 44(4), 1573-1597.

https://doi.org/10.1177/0149206315615400

Hann, C. (2018). Economic anthropology. In H. Callan (Ed.), The international encyclopedia of anthropology (pp. 116). Cambridge, UK: Polity Press. https://doi.org/10.1002/9781118924396.wbiea2194

Hansen, M. T. (1999). The search-transfer problem: The role of weak ties in sharing knowledge across organization subunits. Administrative Science Quarterly, 44(1), 82-111. https://doi.org/10.2307/2667032

Hom, P. W., Tsui, A. S., Wu, J. B., Lee, T. W., Zhang, A. Y., Fu, P. P., \& Li, L. (2009). Explaining employment relationships with social exchange and job embeddedness. Journal of Applied Psychology, 94(2), 277-297. https://doi.org/10.1037/a0013453

Hussain, T., \& Deery, S. (2018). Why do self-initiated expatriates quit their jobs: The role of job embeddedness and shocks in explaining turnover intentions. International Business Review, 27(1), 281-288. https://doi.org/10.1037/a0013453

Inkpen, A. C., \& Tsang, E. W. K. (2005). Social capital, networks, and knowledge transfer. Academy of Management Review, 30(1), 146-165. https://doi.org/10.5465/amr.2005.15281445

Ipe, M. (2003). Knowledge sharing in organizations: A conceptual framework. Human Resource Development Review, 2(4), 337-359. https://doi.org/10.1177/1534484303257985

Jeung, C. W, Yoon, H. J., \& Choi, M. (2017). Exploring the affective mechanism linking perceived organizational support and knowledge sharing intention: A moderated mediation model. Journal of Knowledge Management, 21(4), 946-960. https://doi.org/10.1108/JKM-12-2016-0530 
Organizational socialization and knowledge sharing

Judge, T. A., \& Zapata, C. P. (2015). The person-situation debate revisited: Effect of situation strength and trait activation on the validity of the big five personality traits in predicting job performance. Academy of Management Journal, 58(4), 1149-1179. https://doi.org/10.5465/amj.2010.0837

Karatepe, O. M. (2013). High-performance work practices, work social support and their effects on job embeddedness and turnover intentions. International Journal of Contemporary Hospitality Management, 25(6), 903-921. https://doi.org/10.1108/IJCHM-06-2012-0097

Kim, T. T., \& Lee, G. (2013). Hospitality employee knowledge-sharing behaviors in the relationship between goal orientations and service innovative behavior. International Journal of Hospitality Management, 34, 324-337. https://doi.org/10.1016/j.ijhm.2013.04.009

Le, P. B., \& Lei, H. (2018). The mediating role of trust in stimulating the relationship between transformational leadership and knowledge sharing processes. Journal of Knowledge Management, 22(3), 521-537. https://doi.org/10.1108/JKM-10-2016-0463

Lee, S., Kim, S. L., \& Yun, S. (2018). A moderated mediation model of the relationship between abusive supervision and knowledge sharing. The Leadership Quarterly, 29(3), 403-413. https://doi.org/10.1016/j.leaqua.2017.09.001

Lin, N. (2017). Building a network theory of social capital. In N. Lin, K. S. Cook, \& R. S. Burt (Eds.), Social capital: Theory and research (pp. 3-30). New Brunswick, NJ: Transaction Publishers. https://doi.org/10.4324/9781315129457

McEvily, B., Perrone, V., \& Zaheer, A. (2003). Trust as an organizing principle. Organization Science, 14(1), 91 103. https://doi.org/10.1287/orsc.14.1.91.12814

Mitchell, T. R., Holtom, B. C., Lee, T. W., Sablynski, C. J., \& Erez, M. (2001). Why people stay: Using job embeddedness to predict voluntary turnover. Academy of Management Journal, 44(6), 1102-1121. https://doi.org/10.5465/3069391

Mohan, K. (2017). Behavioral sciences in Thailand: An organizational case study for knowledge management. NID A Case Research Joumal, 9(2), 55-68. Retrieved from https://www.tcithaijo.org/index.php/NCRJ/article/view/111025

Molina-Morales, F. X., Martínez-Fernández, M. T., \& Torlò, V. J., (2011). The dark side of trust: The benefits, costs and optimal levels of trust for innovation performance. Long Range Planning, 44(2), 118-133. https://doi.org/10.1016/j.lrp.2011.01.001

Nahapiet, J., \& Ghoshal, S. (1998). Social capital, intellectual capital, and the organizational advantage. Academy of Management Review, 23(2), 242-266. https://doi.org/10.5465/amr.1998.533225

Nguyen, V. Q., Taylor, G. S., \& Bergiel, E. (2017). Organizational antecedents of job embeddedness. Management Research Review, 40(11), 1216-1235. https://doi.org/10.1108/MRR-11-2016-0255

Nifadkar, S. S. (2018). Filling in the "blank slate": Examining newcomers' schemas of supervisors during organizational socialization. Journal of Management, Online First. https://doi.org/10.1177/0149206318807288

North, K., Maier, R., \& Haas, O. (2018). Knowledge management in digital change. New York, NY: Springer. https://doi.org/10.1007/978-3-319-73546-7

Olaisen, J., \& Revang, O. (2017). The dynamics of intellectual property rights for trust, knowledge sharing and innovation in project teams. International Journal of Information Management, 37(6), 583-589. https://doi.org/10.1016/j.ijinfomgt.2017.05.012

Ozyilmaz, A., Erdogan, B., \& Karaeminogullari, A. (2018). Trust in organization as a moderator of the relationship between self-efficacy and workplace outcomes: A social cognitive theory-based examination. Journal of Occupational and Organizational Psychology, 91(1), 181-204. https://doi.org/10.1111/joop.12189

Pennaforte, A. P. (2016). Organizational supports and individuals commitments through work integrated learning. Higher Education, Skills and Work-Based Learning, 6(1), 89-99. https://doi.org/10.1108/HESWBL-07$\underline{2015-0038}$ 
Rong, P., Li, C., \& Xie, J. (2019). Learning, trust, and creativity in top management teams: Team reflexivity as a moderator. Social Behavior and Personality: An International Journal, 47(5), 1-14. https://doi.org/10.2224/sbp.8096

Sarstedt, M., Bengart, P., Shaltoni, A. M., \& Lehmann, S. (2018). The use of sampling methods in advertising research: A gap between theory and practice. International Journal of Advertising, 37(4), 650-663. https://doi.org/10.1080/02650487.2017.1348329

Sarti, D. (2018). Organizational tenure and knowledge-sharing behaviors. Journal of Workplace Learning, 30(4), 291-307. https://doi.org/10.1108/JWL-03-2017-0027

Sekiguchi, T., Burton, J. P., \& Sablynski, C. J. (2008). The role of job embeddedness on employee performance: The interactive effects with leader-member exchange and organization-based self-esteem. Personnel Psychology, 61(4), 761-792. https://doi.org/10.1111/j.1744-6570.2008.00130.x

Self, T. T., \& Gordon, S. (2019). The impact of coworker support and organizational embeddedness on turnover intention among restaurant employees. Journal of Human Resources in Hospitality \& Tourism, 18(3), 394423. https://doi.org/10.1080/15332845.2019.1599789

Skinner, D., Dietz, G., \& Weibel, A. (2014). The dark side of trust: When trust becomes a 'poisoned chalice'. Organization, 21(2), 206-224. https://doi.org/10.1177/1350508412473866

Smith, P. A. C. (2005). Knowledge sharing and strategic capital. The Learning Organization, 12(6), 563-574. https://doi.org/10.1108/09696470510626766

Soulard, J., Knollenberg, W., Boley, B. B., Perdue, R. R., \& McGehee, N. G. (2018). Social capital and destination strategic planning. Tourism Management, 69, 189-200. https://doi.org/10.1016/j.tourman.2018.06.011

Susskind, A. M., Kacmar, K. M., \& Borchgrevink, C. P. (2003). Customer service providers' attitudes relating to customer service and customer satisfaction in the customer-server exchange. Journal of Applied Psychology, 88(1), 179-187. https://doi.org/10.1037/0021-9010.88.1.179

Szulanski, G. (1996). Exploring internal stickiness: Impediments to the transfer of best practice within the firm. Strategic Management Journal, 17(S2), 27-43. https://doi.org/10.1002/smj.4250171105

Taormina, R. J. (1994). The organizational socialization inventory. International Journal of Selection and Assessment, 2(3), 133-145. https://doi.org/10.1111/j.1468-2389.1994.tb00134.x

Taormina, R. J. (2004). Convergent validation of two measures of organizational socialization. The International Journal of Human Resource Management, 15(1), 76-94. https://doi.org/10.1080/0958519032000157357

Tsai, W. (2001). Knowledge transfer in intraorganizational networks: Effects of network position and absorptive capacity on business unit innovation and performance. Academy of Management Journal, 44(5), 996-1004. https://doi.org/10.5465/3069443

Van Maanen, J. (1975). Police socialization: A longitudinal examination of job attitudes in an urban police department. Administrative Science Quarterly, 20(2), 207-228. https://doi.org/10.2307/2391695

Wang, M. H., \& Yang, T. Y. (2016). Investigating the success of knowledge management: An empirical study of small- and medium-sized enterprises. Asia Pacific Management Review, 21 (2), 79-91. https://doi.org/10.1016/j.apmrv.2015.12.003

Wang, Y. F., \& Zhu, Y. (2009). The relationships among organizational socialization, trust, knowledge sharing and creative behavior. Proceedings of the International Conference on Management and Service Science (pp. 1-5). IEEE. https://doi.org/10.1109/icmss.2009.5304449

Wiesenfeld, B. M., Raghuram, S., \& Garud, R. (2001). Organizational identification among virtual workers: The role of need for affiliation and perceived work-based social support. Journal of Management, 27(2), 213-229. https://doi.org/10.1177/014920630102700205

Williams, M., \& Belkin, L. Y. (2016). Maintaining trust through active meaning construction. Academy of Management Proceedings, 2016(1), 11944. Briarcliff Manor, NY: Academy of Management. https://doi.org/10.5465/ambpp.2016.286 
Wolgast, A., \& Fischer, N. (2017). You are not alone: Colleague support and goal-oriented cooperation as resources to reduce teachers' stress. Social Psychology of Education, 20(1), 97-114. https://doi.org/10.1007/s11218-017-9366-1

Yang, C. J. (2013). The mechanism of impacts of job embeddedness on voluntary turnover in China. Doctoral Dissertation. Boston, MA: Northeastern University.

Yang, I., \& Horak, S. (2019). Emotions, indigenous affective ties, and social network theory - the case of South Korea. Asia Pacific Journal of Management, 36(2), 395-414. https:/ / doi.org/10.1007/s10490-017-9555-7

Yao, Q., \& Le, G. A. (2011). Newcomers' job expectations and adaptations during early stage of organizational socialization: Leader-member exchange as a moderator. Nankai Business Review, 14(2), 52-60.

Yasir, M., \& Majid, A. (2017). Impact of knowledge management enablers on knowledge sharing. World Journal of Entrepreneurship, Management and Sustainable Development, 13(1), 16-33. https://doi.org/10.1108/WJEMSD$\underline{02-2016-0010}$

Zainuddin, Y., \& Noor, A. (2019). The role of job embeddedness and organizational continuance commitment on intention to stay: Development of research framework and hypotheses. KnE Social Sciences, 2019, 10171035. https://doi.org/10.18502/kss.v3i22.5108

Zhou, J., \& George, J. M. (2001). When job dissatisfaction leads to creativity: Encouraging the expression of voice. Academy of Management Journal, 44(4), 682-696. https://doi.org/10.5465/3069410

\section{APPENDIX}

\section{ORGANIZATIONAL SOCIALIZATION}

\section{Coworker support}

1. Other workers have helped me to understand my job requirements.

2. I received a lot of guidance from experienced company members.

3. Almost all my colleagues have given me personal or moral support.

4. My colleagues did a great deal to help me adjust to this company.

5. The interpersonal relations in this company are very good.

\section{Prospects for the future}

1. I can predict my future career path in this organization.

2. The steps in the career ladder are clearly stated in this company.

3. I can readily anticipate my prospects for promotion in this company.

4. I'd like to continue working for this company for many more years.

5. I usually know in advance when I'll receive a new job assignment.

\section{JOB EMBEDDEDNESS}

\section{Organizational links}

1. I have a close relationship with my colleagues at work.

2. I often eat or relax with my leaders or colleagues.

3. I socialize a lot with my colleagues.

\section{Organizational sacrifice}

1. Leaving will have a big impact on my life now.

2. It would be difficult for me to get a better welfare package outside the organization.

3. I have a great job (e.g., personal development, respect, job stability, freedom, etc.).

4. It's hard for me to leave the organization.

5. Leaving my job will cause great loss to me and my family 


\section{Trust}

1. I believe the help I give to my colleagues will be returned in the future.

2. Many of my personal friends are my colleagues.

3. In a long-term view, getting on well with most colleagues is very important to my career development.

4. Generally speaking, I can trust my colleagues to do as they say they will.

5. My colleagues can be relied upon if I meet with critical incidents.

6. My colleagues and I trust each other.

7. Most conflicts among colleagues in the company are over work issues rather than personal conflicts.

\section{Knowledge sharing}

1. In daily work, I take the initiative to share my work-related knowledge to my colleagues.

2. I keep my work experience and never share it out with others easily.

3. I share with others useful work experience and know-how.

4. After learning new knowledge useful to work, I promote it to let more people learn it.

5. I never tell others my work expertise unless it is required in the company.

6. In workplace I take out my knowledge to share with more people.

7. I actively use IT sources available in the company to share my knowledge.

8. So long as the other colleagues need it, I always tell whatever I know without any hoarding.

\section{BIOGRAPHIES}

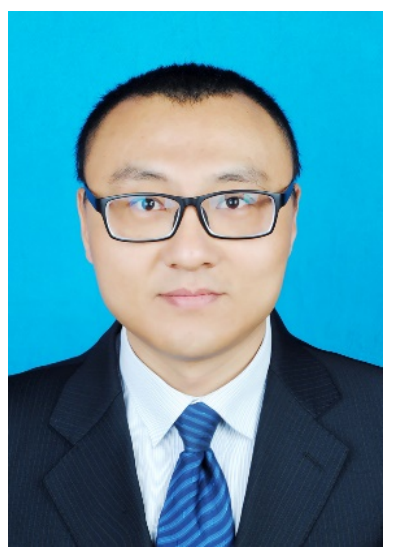

Chunjiang Yang is a professor at College of Business, Yantai Nanshan University, Yantai, China. His research interests include organizational behavior and human resource management.

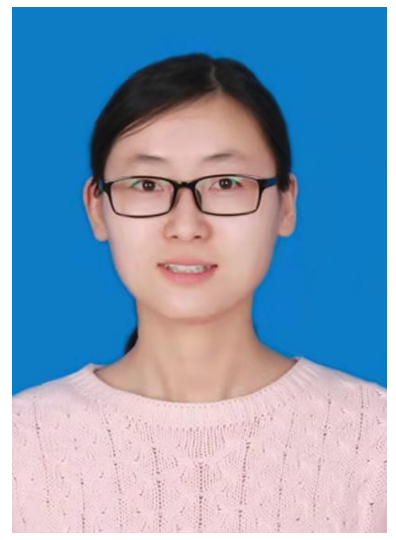

Aobo Chen is a student at School of Economics and Management, Yanshan University, China. Her research interests include organizational behavior and human resource management. 